\title{
Gram Negative Coccus
}

National Cancer Institute

\section{Source}

National Cancer Institute. Gram Negative Coccus. NCI Thesaurus. Code C86422.

Any spherical shaped bacteria that contains low levels of peptidoglycan in its cell wall and stains pink with the Gram staining technique. 